\title{
DIAGNOSIS OF LEVEL OF KNOWLEDGE, OPINION AND PRO-HEALTH BEHAVIOR OF SILESIAN VOIVODESHIP INHABITANTS CONCERNS VITAMIN D AND RISK FACTORS OF ITS DEFICIENCY
}

\author{
DIAGNOZA WIEDZY, OPINII I ZACHOWAŃ PROZDROWOTNYCH \\ MIESZKAŃCÓW WOJEWÓDZTWA ŚLĄSKIEGO DOTYCZĄCA WITAMINY D \\ I CZYNNIKÓW RYZYKA JEJ NIEDOBORU
}

\author{
Department of Basic Biomedical Science, Faculty of Pharmaceutical Sciences in Sosnowiec, \\ Medical University of Silesia, Katowice, Poland \\ Katedra i Zakład Podstawowych Nauk Biomedycznych, Wydział Nauk Farmaceutycznych w Sosnowcu, \\ Śląski Uniwersytet Medyczny w Katowicach
}

\section{ABSTRACT}

INTRODUCTION AND AIM OF THE STUDY. Vitamin D deficiency is a common problem in Poland and worldwide. In the light of recent epidemiological studies, D hypovitaminosis causes not only skeletal diseases, but also other chronic diseases such as immunodeficiency or some types of cancer. The proper knowledge can significantly determine pro-health behaviour, therefore the aim of the study was to analyse the knowledge, opinion and social behaviour regarding vitamin D.

MATERIAL AND METHODS. The survey was conducted among 300 Silesian Voivodeship inhabitants (178 women and 122 men) using an anonymous survey containing 40 questions.

RESULTS. 59\% of people were aware of solar radiation, as a main source of vitamin D in the human body. Sea fish, as the main dietary vitamin D source, were known to $58 \%$ of respondents. The highest number of indications $(67 \%)$ had dairy products, which are poor sources of cholecalciferol. $37 \%$ of people were aware that even a well-balanced diet was not able to provide the required daily dose of vitamin D. $78 \%$ of people in the study group were aware of the calcaemic effect of vitamin D. Only $9 \%$ of respondents were aware of the safe amount of daily sun exposure, sufficient for vitamin D synthesis, while $69 \%$ indicated periods of time longer than recommended. $76 \%$ of the respondents showed a positive attitude to sun exposure. Taking vitamin D supplementation was declared by $45 \%$ of the study participants, while a serum $25(\mathrm{OH}) \mathrm{D}$ level was tested only by $6.5 \%$ of the respondents.

CONCLUSIONS. Insufficient knowledge about the vitamin D sources among the Silesian Voivodeship inhabitants, misconceptions about the possibility to reach adequate blood levels through the diet, and at the same time low consumption of products rich in vitamin D and its supplements, may be the causes of vitamin D deficiencies.

Key words: vitamin $D$, vitamin $D$ deficiency, sources of vitamin $D$, sun exposure, knowledge

\section{STRESZCZENIE}

WPROWADZENIE I CEL. Niedobór witaminy D jest problemem powszechnym w Polsce i na świecie. W świetle ostatnich badań epidemiologicznych hipowitaminoza D jest przyczyną nie tylko schorzeń układu kostnego, ale również innych chorób przewlekłych takich jak niedobory odporności, czy też niektóre typy nowotworów. Stan wiedzy może w istotny sposób determinować zachowania prozdrowotne, dlatego celem pracy była analiza wiedzy, opinii i zachowań społecznych dotyczących witaminy D.

MATERIAL I METODY. Badanie przeprowadzono wśród 300 mieszkańców (178 kobiet i 122 mężczyzn) województwa śląskiego przy użyciu anonimowej ankiety zawierającej 40 pytań. 
WYNIKI. O głównym źródle witaminy D, jakim jest promieniowanie słoneczne, wiedziało 59\% osób. Główne źródło dietetyczne, jakim są ryby morskie, znało 58\% ankietowanych. Największą liczbę wskazań (67\%) miał nabiał, źródło o znikomej zawartości cholekalcyferolu. 37\% osób wiedziało, że dobrze zbilansowana dieta nie zapewnia dobowego zapotrzebowania na witaminę D. 78\% osób w grupie znało funkcje kalcemiczne witaminy D. Zaledwie 9\% ankietowanych znało bezpieczny czas ekspozycji słonecznej, niezbędny do syntezy zalecanej ilości witaminy D, podczas gdy $69 \%$ podało czas dłuższy od rekomendowanego. $76 \%$ respondentów wykazywało pozytywne nastawienie do przebywania na słońcu. Stosowanie suplementów witaminy D zadeklarowało $45 \%$ uczestników badania, natomiast badanie stężenia $25(\mathrm{OH}) \mathrm{D}$ w surowicy przeprowadziło zaledwie $6,5 \%$ ankietowanych.

WNIOSKI. Występująca wśród mieszkańców województwa śląskiego niedostateczna wiedza o źródłach witaminy $\mathrm{D}$, błędne przekonanie o możliwości zapewnienia dobowego zapotrzebowania poprzez dietę, jak również niskie spożycie produktów bogatych w witaminę D i jej suplementów, mogą stanowić przyczynę niedoboru witaminy D.

Słowa kluczowe: witamina $D$, niedobór witaminy $D$, źródła witaminy $D$, ekspozycja słoneczna, wiedza

\section{INTRODUCTION}

The main source of calciferol (vitamin D) for the human body is skin synthesis which occurs under the influence of exposure to ultraviolet radiation in the UVB range. Due to the fact that the second source of vitamin $D$ is made up of a few food products containing only traces of it (except fatty sea fish), calciferol does not meet the classic definition of a vitamin. Even with a well-balanced diet, food covers only 10 to $20 \%$ of the total daily dose. According to the current Polish nutrition standards, the level of vitamin D is set at the level of AI (Adequate Intake), i.e. sufficient consumption. According to Polish standards, the AI for vitamin D in all age groups (except for infants) is $15 \mu \mathrm{g}$ per day (1). Considering the human ability to store vitamin $\mathrm{D}$ in adipocytes, the requirements for vitamin $\mathrm{D}$ does not necessarily need to be met every day.

Vitamin D, formed during skin synthesis and supplied with food, is a prohormone transformed into its biologically active form $-1.25(\mathrm{OH})_{2} \mathrm{D}$ (calcitriol) in a two-stage reaction of hydroxylation in the liver and kidneys. Calcitriol synthesis is multifactorial, regulated and depended mainly on the availability of the hepatic metabolite - 25(OH)D (calcidiol), whose serum level reflects vitamin D status in the organism. According to the current knowledge, the effect of calcitriol is not limited only to maintaining calciumphosphate homeostasis in the body. The $1,25(\mathrm{OH})_{2} \mathrm{D}$ receptors were found in many tissues and organs not directly related to the mineral metabolism (including immune cells). Calcitriol effects the mechanisms responsible for the regulation of the cell cycle: it controls cell division, growth, differentiation and apoptosis through genomic actions on the nuclear VDR receptors (vitamin D receptors) and non-genomic actions on the receptors in the cell membrane. Vitamin $\mathrm{D}$ deficiency is associated not only with rickets in

\section{WSTĘP}

Głównym źródłem kalcyferolu (witamina D) dla organizmu człowieka jest synteza skórna zachodząca pod wpływem ekspozycji na promieniowanie ultrafioletowe z zakresu UVB. Ze względu na to, że drugie źródło witaminy D stanowią nieliczne produkty spożywcze zawierające jedynie śladowe jej ilości (za wyjątkiem tłustych ryb morskich), kalcyferol nie spełnia klasycznej definicji witaminy. Nawet przy dobrze zbilansowanej diecie, żywność pokrywa zaledwie od 10 do $20 \%$ dobowego zapotrzebowania organizmu. Według aktualnych, polskich norm żywienia, norma dla witaminy D ustalona jest na poziomie AI (Adequate Intake), czyli wystarczającego spożycia. Zgodnie z polskimi normami AI dla witaminy D wynosi we wszystkich grupach wiekowych (za wyjątkiem niemowląt) $15 \mu \mathrm{g}$ na dobę (1). Biorąc pod uwagę zdolność magazynowania witaminy $\mathrm{D} w$ adipocytach, zapotrzebowanie na ten składnik nie musi być bezwzględnie realizowane każdego dnia.

Witamina D powstająca podczas syntezy skórnej, jak i dostarczana z pokarmem, jest prohormonem przekształcanym do formy aktywnej biologicznie $1,25(\mathrm{OH})_{2} \mathrm{D}$ (kalcytriol) na drodze dwuetapowej reakcji hydroksylacji zachodzącej w wątrobie i nerkach. Podlegająca wieloczynnikowej regulacji synteza kalcytriolu zależy głównie od dostępności metabolitu wątrobowego - 25(OH)D (kalcydiol), którego stężenie w surowicy odzwierciedla stan zaopatrzenia organizmu w witaminę D. Zgodnie z obecną wiedzą, działanie kalcytriolu nie jest ograniczone jedynie do utrzymywania homeostazy wapniowo-fosforanowej w organizmie. Obecność receptorów dla $1,25(\mathrm{OH})_{2} \mathrm{D}$ stwierdzono w wielu tkankach i narządach niezwiązanych bezpośrednio z gospodarką mineralną ustroju (min. w komórkach układu immunologicznego). Poprzez działanie genomowe na receptory jądrowe VDR (vitamin D receptor) oraz działanie niegenomowe na receptory w błonie komórkowej, kalcytriol wpływa na mechanizmy odpowiedzialne 
children, osteoporosis and osteomalacia in adults, but also with an increased incidence of cardiovascular, autoimmune, neurodegenerative diseases, certain types of cancer (breast, prostate, colon) as well as an increased risk of developing allergies, diabetes, immunodeficiency and depression $(2,3)$.

To provide proper calcemic effect, the recommended serum levels of $25(\mathrm{OH}) \mathrm{D}$ is above 20 $\mathrm{ng} / \mathrm{ml}(50 \mathrm{nmol} / \mathrm{l})$, however, the definition of vitamin D deficiency has not been clearly established so far. Considering the calcidiol level at which secondary hyperparathyroidism does not occur, as well as the potential numerous, not classic actions (pleiotropic), most experts consider the optimal level to be 30 $50 \mathrm{ng} / \mathrm{ml}(75-125 \mathrm{nmol} / \mathrm{l})$. Taking into account the diagnostic criteria above, it is estimated that 25(OH)D deficiency affects over a billion people worldwide. It occurs regardless of gender, age, level of education and place of residence. Based on an epidemiological study conducted by Płudowski et al. (4) in a representative group of 5,775 large Polish city's inhabitants, vitamin D deficiency was found among $89.9 \%$ of the respondents. This is particularly disturbing that the diagnosis of severe deficiency, defined as $25(\mathrm{OH}) \mathrm{D}$ level below $10 \mathrm{ng} / \mathrm{ml}$, was found among $16 \%$ of the participants (4).

Among many factors responsible for the occurrence of vitamin D deficiencies, the most important are: the modern lifestyle associated with limited exposure to direct sunlight and an inefficient exogenous source. Public awareness of this issue is essential to counter many health consequences of 25-hydroxyvitamin D deficiency. The proper knowledge can significantly determine pro-health behaviour, therefore the aim of the study was to analyse the knowledge, opinion and behaviour of Silesian Voivodeship inhabitants concerns vitamin D and risk factors of its deficiency. An additional goal was to extend the analysis by including respondent's age, gender and level of education, which allowed to indicate the target group for vitamin D deficiency control public health programmes.

\section{MATERIAL AND METHODS}

The study was conducted at the turn of 2019 and 2020, among 300 adult residents of the GZM Metropolis (GZM). The characteristic of the study group was presented in Table I. The study used an anonymous, proprietary questionnaire containing 40 questions: 10 open, 7 half-open, 18 singlechoice closed and 5 questions with the possibility of choosing more than one answer. The second part of the questionnaire included questions related to the behaviour of respondents influencing the vitamin za regulację cyklu komórkowego: kontroluje podział, wzrost, różnicowanie i apoptozę komórki. Niedobory witaminy D wiązane są nie tylko z krzywicą u dzieci, osteoporozą i osteomalacją u dorosłych, ale również ze zwiększoną zapadalnością na choroby sercowo-naczyniowe, autoimmunologiczne, neurodegeneracyjne, niektóre typy nowotworów (sutka, prostaty, jelita grubego), a także ze zwiększonym ryzykiem wystąpienia alergii, cukrzycy, upośledzenia odporności i stanów depresyjnych $(2,3)$.

Dla zapewnienia prawidłowej funkcji kalcemicznej rekomendowana wartość stężenia $25(\mathrm{OH}) \mathrm{D}$ w surowicy powinna wynosić powyżej $20 \mathrm{ng} / \mathrm{ml}(50 \mathrm{nmol} / \mathrm{l})$, jednakże jak do tej pory definicja niedoboru witaminy D nie została jednoznacznie uzgodniona. Biorąc pod uwagę stężenie kalcydiolu w surowicy, przy którym nie dochodzi do wtórnej nadczynności przytarczyc, jak również potencjalne liczne działania nieklasyczne (plejotropowe), większość ekspertów za optymalne stężenie uznaje zakres 30-50 ng/ml (75-125 nmol/1). Uwzględniając powyższe kryteria diagnostyczne, szacuje się, że niedobór $25(\mathrm{OH}) \mathrm{D}$ dotyczy przeszło miliarda ludzi na świecie. Występuje niezależnie od płci, wieku, wykształcenia i miejsca zamieszkania. Na podstawie badania epidemiologicznego, przeprowadzonego przez Płudowskiego i wsp. (4) na reprezentatywnej grupie 5775 mieszkańców dużych polskich miast, niedobór witaminy D stwierdzony został u $89,9 \%$ badanych. Szczególnie niepokoi zdiagnozowanie ciężkiego niedoboru, zdefiniowanego jako stężenie $25(\mathrm{OH}) \mathrm{D}$ wynoszące poniżej $10 \mathrm{ng} / \mathrm{ml}$, u 16\% badanych osób (4).

Spośród wielu czynników odpowiedzialnych za występowanie niedoborów witaminy $\mathrm{D}$ do najważniejszych należą: współczesny styl życia, związany z ograniczeniem ekspozycji na światło słoneczne, oraz mało wydajne źródło egzogenne. Aby przeciwdziałać licznym konsekwencjom zdrowotnym powstałym w następstwie niedoboru 25-hydroksywitaminy D, kluczowe znaczenie ma społeczna świadomość istnienia problemu. Stan wiedzy może w istotny sposób determinować zachowania prozdrowotne, dlatego celem pracy była analiza wiedzy, opinii i zachowań mieszkańców województwa śląskiego dotyczących witaminy $\mathrm{D}$, jak również czynników ryzyka występowania jej niedoborów. Celem dodatkowym było poszerzenie analizy, uwzględniając wiek, płeć i wykształcenie ankietowanych, co pozwoli wskazać grupę, do której szczególnie powinny być kierowane programy profilaktyczne zapobiegające niedoborom witaminy $\mathrm{D}$.

\section{MATERIAŁ I METODY}

Badanie prowadzone było na przełomie 2019 i 2020 roku wśród 300 pełnoletnich mieszkańców Górnośląsko-Zagłębiowskiej Metropolii (GZM). Charaktery- 
D status in the body. The questions included, inter alia, the time spent outdoors, the vitamin D supplementation and the frequency of intake foods rich in vitamin D. The respondents' awareness of necessity to monitor vitamin D metabolite level in the blood and the opinion on supplementation and food fortification were also examined. The third part of the questionnaire concerned the socio-demographic data: age, gender and level of education.

Table I. Characteristics of study group

Tabela I. Charakterystyka grupy badanej

\begin{tabular}{|c|c|c|c|}
\hline \multicolumn{2}{|c|}{} & $\mathrm{n}$ & $\%$ \\
\hline \multirow{3}{*}{ Gender } & Women & 178 & 59 \\
\cline { 2 - 4 } & Men & 122 & 41 \\
\hline \multirow{3}{*}{ Age } & $<35$ years & 121 & 40.3 \\
\cline { 2 - 4 } & $35-50$ years & 118 & 39.3 \\
\cline { 2 - 4 } & $>51$ years & 61 & 20.3 \\
\hline \multirow{3}{*}{ Education } & High & 82 & 27.3 \\
\cline { 2 - 4 } & Secondary & 169 & 56.3 \\
\cline { 2 - 4 } & Low & 49 & 16.3 \\
\hline
\end{tabular}

A traditional method was used for data collection. The questionnaires were distributed in public places. A pilot survey was performed before the actual research to check the intelligibility of the questions, to identify a possible suggestive questions and to establish a logical sequence of the questions. The results of a pilot study involving 30 people were not included in the actual analysis.

The statistical analysis was performed using STATISTICA 13 software. Descriptive statistic was used in the study. The results were presented as a percentage scale. The survey indications were compared using the chi2 $(\chi 2)$ test of independence regard to gender, age and level of education. Statistical significance was set at $\mathrm{p} \leq 0.05$.

\section{RESULTS}

Dairy products, solar radiation and fish were most frequently mentioned the vitamin $\mathrm{D}$ sources by the respondents (Fig. 1). Women (W) compared to men (M) more often indicated the following sources of vitamin D: sun (W vs. M, $64 \%$ vs. $52 \%$, p $<0.05$ ), fish $(66 \%$ vs. $48 \%, p<0.01)$ and chicken eggs $(46 \%$ vs. $33 \%, \mathrm{p}<0.05)$. Knowledge about the vitamin D sources also depended on the respondents age. People aged $<35$ years, 35-50 years and $>50$ years indicated fish with the frequency of $44 \%, 67 \%$, $70 \%$, respectively, $\mathrm{p}<0.001$; chicken eggs with the frequency of $30 \%, 49 \%, 44 \%$, respectively, $\mathrm{p}$ styka grupy badanej przedstawiona została w Tabeli I. W badaniu posłużono się anonimową, autorską ankietą zawierającą 40 pytań: 10 otwartych, 7 półotwartych, 18 pytań zamkniętych jednokrotnego wyboru i 5 z możliwością wyboru więcej niż jednej odpowiedzi. W pierwszej części kwestionariusza sprawdzona została wiedza ankietowanych na temat witaminy D. Pytania dotyczyły między innymi: źródeł, funkcji fizjologicznych witaminy D, czasu ekspozycji na promieniowanie słoneczne niezbędnego do wytworzenia witaminy $\mathrm{D}$ w ilości pokrywającej dzienne zapotrzebowanie, czynników ograniczających skórną syntezę oraz konsekwencji zdrowotnych powstałych w wyniku niedoboru witaminy D. W drugiej części ankiety zawarte były pytania odnoszące się do zachowań osób badanych wpływających na stan zaopatrzenia organizmu w witaminę D. Pytano między innymi o czas przebywania poza pomieszczeniami zamkniętymi, stosowanie suplementów witaminy D oraz częstotliwość spożywania produktów bogatych w witaminę $\mathrm{D}$. Zbadana została również świadomość respondentów związana $\mathrm{z}$ monitorowaniem stężenia metabolitu witaminy $\mathrm{D}$ w surowicy oraz opinia dotycząca suplementacji i fortyfikacji żywności. Trzecia część ankiety dotyczyła danych socjo-demograficznych osób badanych: wieku, płci i wykształcenia.

W pozyskiwaniu danych posłużono się techniką tradycyjną. Ankiety były rozdawane w miejscach użyteczności publicznej. Przed właściwym badaniem ankietowym przeprowadzone zostało badanie pilotażowe, w celu sprawdzenia, czy pytania były sformułowane w sposób zrozumiały dla respondentów, niesugerujący odpowiedzi i w logicznej kolejności. Wyniki badania wstępnego, w którym wzięło udział 30 osób, nie zostały włączone do właściwej analizy.

Analizę statystyczną przeprowadzono z wykorzystaniem programu komputerowego Statistica 13. W badaniu zastosowano analizę statystyczną opisową. Wyniki zostały przedstawione w skali procentowej. Odpowiedzi na pytania zawarte $\mathrm{w}$ ankiecie były porównywane testem niezależności $\operatorname{chi}^{2}\left(\chi^{2}\right)$ w odniesieniu do płci, wieku, wykształcenia. Wyniki znamienne statystycznie uznano na poziomie $\mathrm{p} \leq 0,05$.

\section{WYNIKI}

Najczęściej wymienianymi przez respondentów źródłami witaminy D były: nabiał, promieniowanie słoneczne oraz ryby (Ryc.1). Kobiety (K), w porównaniu do mężczyzn (M), częściej jako źródło witaminy D podawały: słońce (K vs M, $64 \%$ vs $52 \%$, p $<0,05)$, ryby $(66 \%$ vs $48 \%, p<0,01)$ oraz jaja kurze ( $46 \%$ vs $33 \%, p<0,05)$. Wiedza na temat źródeł witaminy $\mathrm{D}$ zależała również od wieku ankietowanych. Osoby w wieku $<35$ lat, 35-50 lat $\mathrm{i}>50$ lat wskazywały ryby z częstością odpowiednio: $44 \%, 67 \%, 70 \%, p<0,001$, jaja kurze $\mathrm{z}$ częstością 


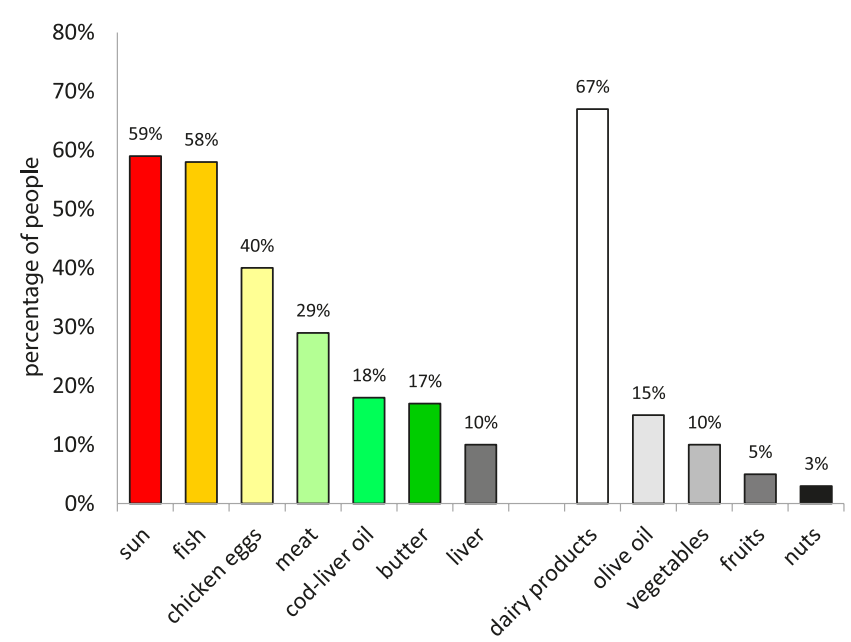

Figure 1. Respondent's knowledge about the vitamin D sources

Rycina 1. Wiedza ankietowanych na temat źródeł witaminy D

$<0.01$; milk and dairy products with the frequency of $74 \%, 66 \%, 43 \%$, respectively, $\mathrm{p}<0.001 .10 \%$ of the respondents could not name any food source of vitamin $\mathrm{D}$, and some erroneous sources were also given, such as: vegetable oils, vegetables and fruits (Fig. 1). The level of education has not significantly affected the respondents' knowledge about vitamin D sources.

$44 \%$ of the respondents were convinced that the total daily dose of vitamin D is provided with a well-balanced diet. 19\% of the respondents chose the answer "I do not know" and only $37 \%$ of the respondents answered this question correctly. The frequency indicating the correct answer was significantly lower among the oldest age group $(<35$ years vs. $35-50$ years vs. $>50$ years, $56 \%, 50 \%, 26 \%$, respectively, $\mathrm{p}<0.05$ ), but there were no statistically significant differences depending on the gender and level of education.

The respondents' knowledge about the physiological functions of calciferol was verified in an open question. $78 \%$ of people in the study group were aware of the role of vitamin D in the calciumphosphate balance and in the proper mineralization of bone tissue. Women indicated calcemic effect more often than men $2 \%$ vs. $73 \%, p<0.05)$. Other vitamin D functions were also mentioned: $24 \%$ of respondents indicated strengthening immunity ( $30 \%$ of women and $16 \%$ of men, $p<0.05$ ), $15 \%$ anticaries effect and 14\% anti-depressant effect. Other pleiotropic effects were mentioned with much less frequency: proper appearance and function of skin $(5.3 \%)$, cardiovascular disease protection $(4.7 \%)$, anti-diabetic effect (1.3\%), anti-allergic effect (1\%), however, only 2 people knew about the anti-cancer odpowiednio: $30 \%, 49 \%, 44 \%, \mathrm{p}<0,01$, mleko i produkty mleczne z częstością odpowiednio: $74 \%, 66 \%, 43 \%$, $\mathrm{p}<0,001.10 \%$ ankietowanych nie potrafiło wymienić żadnych źródeł pokarmowych witaminy D, podawano również błędne źródła, takie jak: oleje roślinne, warzywa i owoce (Ryc.1). Wykształcenie nie wpłynęło istotnie na posiadaną przez respondentów wiedzę na temat źródeł witaminy D.

$44 \%$ osób badanych było zdania, że dobrze zbilansowana dieta zapewnia całkowite dzienne zapotrzebowanie organizmu na witaminę D. 19\% badanych wybrało odpowiedź „nie wiem”, a prawidłowo na to pytanie odpowiedziało tylko 37\% respondentów. Częstość wskazywania poprawnej odpowiedzi była istotnie statystycznie mniejsza w najstarszej grupie wiekowej $(<35$ lat vs $35-50$ lat vs $>50$ lat, $56 \%, 50 \%, 26 \%, \mathrm{p}<0,05)$, nie stwierdzono natomiast istotnych statystycznie różnic w zależności od płci i wykształcenia ankietowanych.

Wiedza ankietowanych na temat funkcji fizjologicznych kalcyferolu zweryfikowana została pytaniem otwartym. 78\% osób w grupie badanej było świadomych roli witaminy $\mathrm{D} w$ gospodarce wapniowo-fosforanowej i prawidłowej mineralizacji tkanki kostnej. Częściej na funkcję kalcemiczną wskazywały kobiety niż mężczyźni $(82 \%$ vs $73 \%, p<0,05)$. Zostały również wymienione niektóre inne funkcje witaminy D: $24 \%$ respondentów wskazało na wzmacnianie odporności (30\% kobiet i 16\% mężczyzn, $\mathrm{p}<0,05$ ), 15\% na działanie przeciwpróchnicze, a $14 \%$ antydepresyjne. Pozostałe funkcje plejotropowe wymieniane były z dużo mniejszą częstością: prawidłowy wygląd i funkcjonowanie skóry $(5,3 \%)$ ochrona przed chorobami układu sercowo -naczyniowego (4,7\%), działanie przeciwcukrzycowe $(1,3 \%)$, antyalergiczne ( $1 \%)$, natomiast o działaniu przeciwnowotworowym wiedziały zaledwie 2 osoby. 15,3\% ankietowanych nie wymieniło żadnej fizjologicznej funkcji kalcyferolu.

W celu sprawdzenia wiedzy ankietowanych na temat konsekwencji zdrowotnych mogących wynikać $\mathrm{z}$ niedoboru witaminy D posłużono się pytaniem koniunktywnym. Odpowiedź „nie wiem” zaznaczyło w tym pytaniu jedynie 3,3\% osób (Ryc.2). Na ryzyko krzywicy i osteoporozy wskazało odpowiednio: $88 \%$ i $87 \%$ ankietowanych, a na liczbę pozytywnych wskazań obu chorób istotny statystycznie wpływ miała płeć żeńska respondentów. Zaburzenia odporności zostały wybrane przez połowę badanych osób, wśród których istotnie większą część stanowiły kobiety (60\% kobiet vs $35 \%$ mężczyzn, $\mathrm{p}<0,001)$.

$23 \%$ ankietowanych zadeklarowało brak wiedzy na temat czasu dziennej ekspozycji słonecznej, wystarczającego do syntezy witaminy D przy odsłonięciu $18 \%$ powierzchni ciała. Poprawnej odpowiedzi udzieliło zaledwie 9\% osób w grupie badanej, a pozostała jej część w różnym stopniu przeszacowała bezpieczny czas prze- 
effect. $15.3 \%$ of respondents did not mention any physiological effect of calciferol.

In order to test the respondents' knowledge about the health consequences that may occur from vitamin $\mathrm{D}$ deficiency, a conjunctive question was used. The answer "I do not know" was marked by only $3.3 \%$ of people with this question (Fig. 2). The risk of rickets and osteoporosis was indicated by $88 \%$ and $87 \%$ of people, respectively, and the number of positive indications of both diseases was significantly influenced by the female gender of the respondents. Immunity disorders were selected by half of the respondents, with a significant majority of women $(60 \%$ of women vs. $35 \%$ of men, $p<0.001$ ).

$23 \%$ of respondents declared lack of knowledge about the sufficient daily sun exposure for vitamin D synthesis while $18 \%$ of the body surface is uncovered. The correct answer was provided only by $9 \%$ of people in the study group, the rest overestimated the

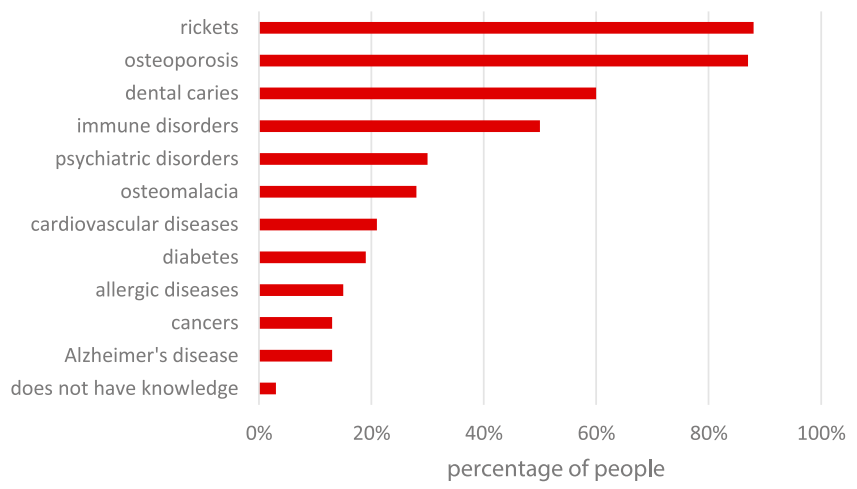

Figure 2. Respondent's knowledge about the health consequences of vitamin D deficiency

Rycina 2. Wiedza ankietowanych na temat konsekwencji zdrowotnych wynikających z niedoboru witaminy D

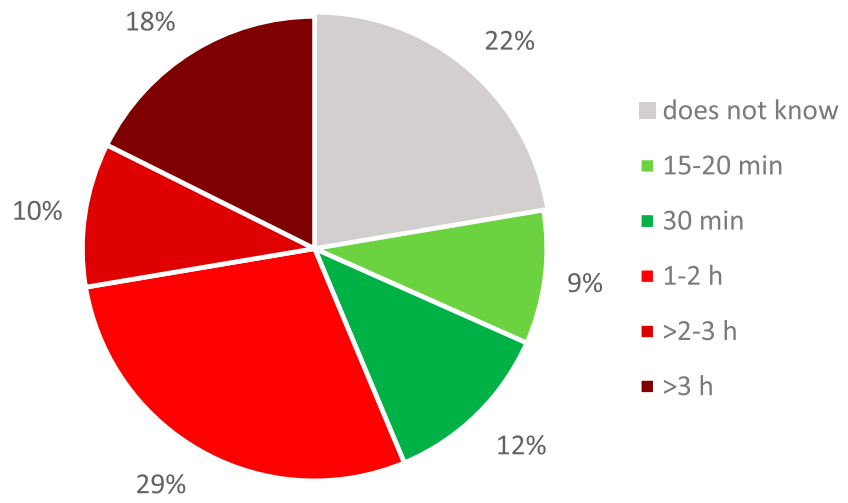

Figure 3. Respondent's knowledge about the minimum time of sun exposure sufficient for synthesis of daily dose of vitamin D

Rycina 3. Wiedza ankietowanych na temat minimalnego czasu ekspozycji słonecznej potrzebnej do wytworzenia dobowej dawki witaminy D

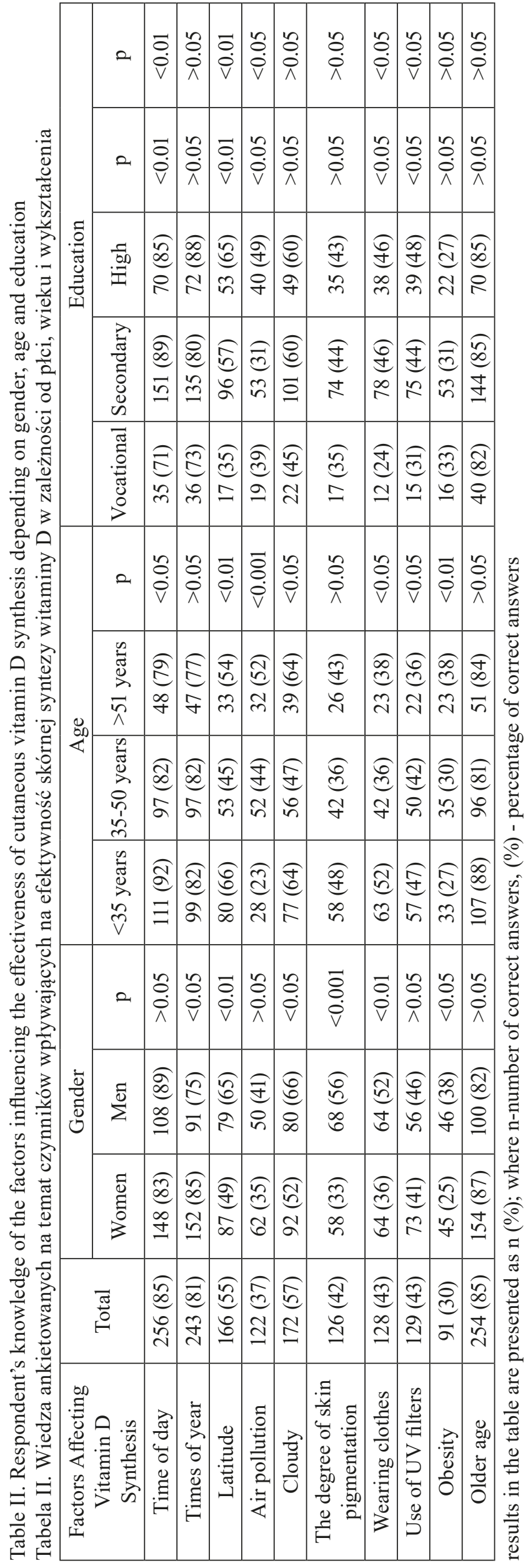


safe time spent in the sun, in varying degrees (Fig. 3). In Table II the respondents' knowledge of the factors influencing the effectiveness of cutaneous vitamin D synthesis depending on gender, age and education was presented.

The recommended daily supplementation dose of vitamin D, according to the 2018 guidelines, amounting 800-2000 IU for an adult, was correctly indicated by $41 \%$ of respondents. $19 \%$ indicated a lower dose and $26 \%$ more than the recommended dose. $15 \%$ of respondents declared lack of knowledge in this area.

Further part of the questionnaire analysed the behaviour of the respondents that may affect the vitamin D levels in their body. $76 \%$ of respondents showed a positive attitude to sun exposure: the answer "I willingly undergo short sun exposures" was provided by $42 \%$ of people and "I spend as much time as possible in the sun" $-34 \%$. The remaining $24 \%$ of the surveyed group declared avoiding direct sunlight: $4 \%$ indicated the answer "when the sun is shining, I do not leave the house" and $20 \%$ chose "I spend my time only in the shade". The most common reasons for limiting the frequency and duration of sun exposure were: fear of skin cancer $(69 \%$ of all responses, $\mathrm{F}$ vs. M, $74 \%$ vs. $62 \%, p<0.05)$, avoidance of heat $(60 \%)$ and fear of photoaging ( $48 \%$ of people, F vs. M, $60 \%$ vs. $32 \%, \mathrm{p}<0.001)$.

In this study the respondents' eating behaviour were analysed. In Figure 4 the frequency of consumption of foods rich in vitamin D in the entire study group was shown, while in Table III only statistically significant differences in the frequency of consumption depending on the age of the respondents were presented. The attitude of the respondents to the fortification of foods with vitamin D was also examined: between $53 \%$ of people was positive, $29 \%$

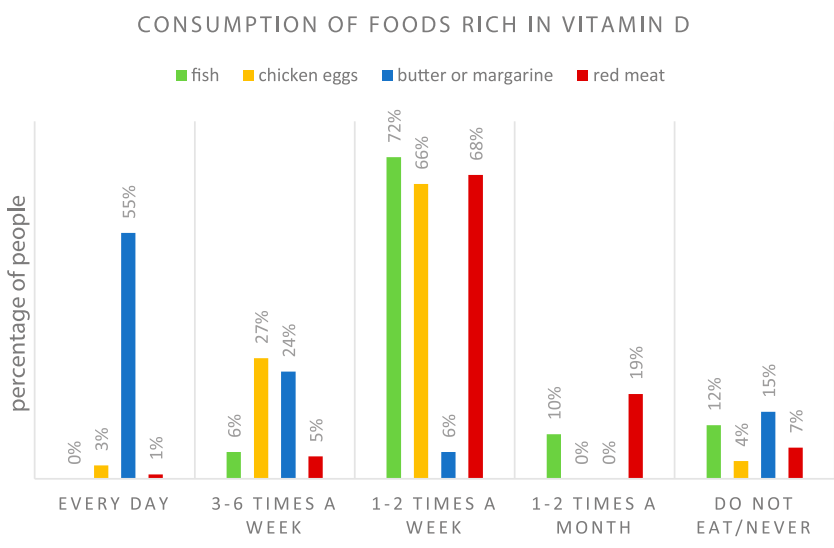

Figure 4. The frequency of consumption of foods rich in vitamin D

Rycina 4. Częstotliwość spożywania produktów bogatych w witaminę D bywania na słońcu (Ryc. 3). W Tabeli II przedstawiona została wiedza respondentów na temat czynników wpływających na efektywność skórnej syntezy witaminy D w zależności od płci, wieku i wykształcenia.

Zalecaną dobową dawkę suplementacyjną witaminy D, według wytycznych z 2018 roku wynoszącą dla osoby dorosłej $800-2000 \mathrm{IU}$, prawidłowo wybrało $41 \%$ ankietowanych. 19\% wskazało na dawkę mniejszą, a 26\% na większą od zalecanej. $15 \%$ respondentów zadeklarowało brak wiedzy w tym zakresie.

W dalszej części kwestionariusza dokonano analizy zachowań ankietowanych mogących wpływać na stan zaopatrzenia organizmu w witaminę D. $76 \%$ respondentów wykazało pozytywne nastawienie do przebywania na słońcu: odpowiedź „,chętnie poddaję się krótkim ekspozycjom słonecznym" wybrało $42 \%$ osób, a „spędzam na słońcu możliwie jak najwięcej czasu” $34 \%$. Pozostałe $24 \%$ badanych osób deklarowało unikanie bezpośredniego nasłonecznienia: 4\% wskazało odpowiedź „gdy świeci słońce nie wychodzę z domu”, a $20 \%$ wybrało „spędzam czas wyłącznie w cieniu”. Do najczęściej wymienianych przez respondentów powodów ograniczania częstotliwości i czasu ekspozycji słonecznej należały: obawa przed nowotworami skóry (69\% wszystkich odpowiedzi, K vs M, $74 \%$ vs $62 \%$, $\mathrm{p}<0,05)$, unikanie gorąca $(60 \%)$ oraz obawa przed fotostarzeniem ( $48 \%$ osób, K vs M, $60 \%$ vs $32 \%$, p $<0,001$ ).

$\mathrm{W}$ badaniu przeanalizowane zostały zachowania żywieniowe respondentów. Rycina 4 przedstawia częstotliwość spożywania produktów spożywczych bogatych

Table III. Percentage of people consuming foods rich in vitamin $\mathrm{D}$ with a certain frequency in three age groups Tabela III. Odsetek osób spożywających produkty bogate w witaminę D z określoną częstością w trzech grupach wiekowych

\begin{tabular}{|c|c|c|c|c|}
\hline \multirow{2}{*}{ Frequency } & $\begin{array}{c}<35 \\
\text { years }\end{array}$ & $\begin{array}{c}35-55 \\
\text { years }\end{array}$ & $\begin{array}{c}>55 \\
\text { years }\end{array}$ & $\mathrm{p}$ \\
\cline { 2 - 5 } & \multicolumn{5}{|c|}{ Consumption of fish } \\
\hline $\begin{array}{c}\text { 1-2 times / } \\
\text { week }\end{array}$ & 62 & 75 & 85 & $<0.01$ \\
\hline do not eat & 17 & 8 & 7 & $<0.05$ \\
\hline \multicolumn{5}{|c|}{ Consumption of chicken eggs } \\
\hline $\begin{array}{c}\text { 1-2 times / } \\
\text { week }\end{array}$ & 55 & 89 & 72 & $<0.001$ \\
\hline do not eat & 7 & 3 & 0 & $<0.05$ \\
\hline \multicolumn{6}{|c|}{ Consumption of butter or margarine } \\
\hline \multicolumn{6}{|c|}{ daily } & 46 & 62 & 61 & $<0.05$ \\
\hline do not eat & 24 & 7 & 11 & $<0.001$ \\
\hline \multicolumn{5}{|c|}{ Consumption of red meat } \\
\hline $\begin{array}{c}\text { 1-2 times / } \\
\text { week }\end{array}$ & 42 & 91 & 85 & $<0.001$ \\
\hline do not eat & 16 & 7 & 5 & $<0.05$ \\
\hline
\end{tabular}


of the group were undecided, and between $18 \%$ of the respondents it was negative. People opposing the fortification of foods with vitamin $\mathrm{D}$ provided the following reasons: the need to achieve an appropriate level of this vitamin from natural sources - a proper $\operatorname{diet}(35 \%)$ or sun exposure $(13.3 \%)$, a negative attitude to interfere in foods (33.3\%), fear of overdosing $(10 \%) .8 .3 \%$ of the respondents did not provide a justification.

Taking vitamin D supplementation was declared by $45 \%(n=136)$ of the study participants: $53 \%$ of women and $34 \%$ of men $(p<0.01)$. Only $43.4 \%$ of the respondents were aware of the dose of vitamin $\mathrm{D}$ in their supplement $(50 \%$ of women and $26.2 \%$ of men, $\mathrm{p}<0.01)$. Cod-liver oil and multivitamin supplements (43\% each) were most often mentioned among men, while supplements or medications containing only vitamin D (31\%) less often. Supplements containing only vitamin $\mathrm{D}$ were used most often in the group of women $-59 \%$ of indications, and cod-liver oil and multivitamin supplements were taken by $23 \%$ and $19 \%$ of the participants, respectively. $52.9 \%$ of people declared taking vitamin D supplements irregularly, $16.2 \%$ regularly throughout the year, while among people who supplemented vitamin D regularly from October to March (30.9\%) there were statistically significant more women than men $(35,1 \%$ vs. $21.4 \%$, $\mathrm{p}<0.01)$. People without supplementation $(55 \%$, $\mathrm{n}=164$ ) explained their attitude as follows: "I do not the need" (36.6\%), "I do not think I have a deficiency: I eat properly and/or stay in the sun" (35.4\%), "I feel good" (15\%), "I have a negative attitude towards drugs/supplements" (9.14\%), "Not recommended by a doctor" (3\%), while only one person wrote: "I do not have vitamin D deficiency, it has been confirmed by laboratory tests".

$32 \%$ of respondents, $38 \%$ of women and $24 \%$ of men $(p<0.01)$ were aware of the possibility of testing vitamin D levels in the body, as well as significantly more people with higher and secondary education compared to people with vocational education (respectively: $44 \%, 30 \%$ vs. $18 \%$, p $<0.01$ ). Only $6.5 \%$ $(\mathrm{n}=20)$ of the study group tested the serum level of $25(\mathrm{OH}) \mathrm{D}$ in the blood, 16 women and 4 men (11 people had the test prescribed by a doctor while treating the existing disease, and 9 people made an independent decision out of concern about their health).

The main sources of information about vitamin D were mass media: internet (55\%), television (28.7\%) and press $(18.7 \%) .20 .7 \%$ of people were informed by family members or friends, $14 \%$ indicated school education and only $9.7 \%$ of people obtained information from a doctor or other healthcare professional. w witamine $\mathrm{D}$ w całej grupie badanej, natomiast w Tabeli III zamieszczono tylko istotne statystycznie różnice częstotliwości ich spożycia w zależności od wieku ankietowanych. Zbadano również stosunek ankietowanych do fortyfikacji żywności w witaminę D: u 53\% osób był on pozytywny, $29 \%$ było niezdecydowanych, natomiast u $18 \%$ ankietowanych był on negatywny. Osoby przeciwne wzbogacaniu żywności w witaminę D podawały następujące uzasadnienia swojej postawy: potrzeba osiągnięcia odpowiedniego poziomu tej witaminy naturalnymi źródłami - odpowiednią dietą (35\%) lub ekspozycją słoneczną (13,3\%), negatywny stosunek do ingerowania w żywność $(33,3 \%)$, obawa przed przedawkowaniem (10\%). 8,3\% ankietowanych nie podało uzasadnienia swojej postawy.

Stosowanie suplementów witaminy D zadeklarowało $45 \%$ (n=136) uczestników badania: 53\% kobiet i 34\% mężczyzn $(p<0,01)$. Zaledwie $43,4 \%$ respondentów znało dawkę dobową przyjmowanego preparatu witaminy D (50\% kobiet i $26,2 \%$ mężczyzn, $p<0,01)$. Wśród mężczyzn najczęściej wymieniany był tran i preparaty wielowitaminowe (po 43\%), natomiast rzadziej suplementy lub leki zawierające samą witaminę D (31\%). W grupie kobiet najczęściej stosowane były suplementy zawierające wyłącznie witaminę D - 59\% wskazań, a tran i preparaty wielowitaminowe przyjmowane były odpowiednio przez 23\% i 19\% uczestniczek badania. $52,9 \%$ osób zadeklarowało przyjmowanie suplementów witaminy D nieregularnie, $16,2 \%$ regularnie przez cały rok, natomiast wśród osób suplementujących witaminę D regularnie od października do marca $(30,9 \%)$ istotnie statystycznie więcej było kobiet w porównaniu do mężczyzn $(35,1 \%$ vs $21,4 \%, \mathrm{p}<0,01)$. Osoby nieprowadzące suplementacji $(55 \%, n=164)$ podawały następujące uzasadnienia swojej postawy: „Nie widzę takiej potrzeby” $(36,6 \%)$, „Myślę, że nie mam niedoboru: prawidłowo się odżywiam i/lub przebywam na słońcu” $(35,4 \%)$, „Dobrze się czuję" (15\%), „Mam negatywny stosunek do leków/suplementów” (9,14\%), „Nie zalecił lekarz” (3\%), natomiast tylko jedna osoba wpisała: „Nie mam niedoboru witaminy $\mathrm{D}$, co potwierdziłam badaniem laboratoryjnym".

O możliwości przeprowadzenia badania poziomu witaminy D w organizmie wiedziało $32 \%$ ankietowanych, $38 \%$ kobiet i $24 \%$ mężczyzn ( $\mathrm{p}<0,01$ ), jak również istotnie statystycznie więcej osób $z$ wykształceniem wyższym i średnim w porównaniu do osób z wykształceniem zawodowym (odpowiednio: $44 \%, 30 \%$ vs $18 \%$, $\mathrm{p}<0,01)$. Badanie stężenia $25(\mathrm{OH}) \mathrm{D}$ w surowicy przeprowadziło zaledwie $6,5 \%(\mathrm{n}=20)$ badanej grupy, 16 kobiet i 4 mężczyzn (11 osób wykonało badanie z polecenia lekarza w trakcie leczenia istniejącej choroby, a u 9 osób była to samodzielna decyzja wynikająca z troski o zdrowie). 


\section{DISCUSSION}

The results obtained in this study revealed a serious knowledge deficit about the vitamin D sources. Only $59 \%$ of the respondents were aware of solar radiation, as a main source of vitamin D in the human body. In similar studies carried out in Great Britain (5) and France (6), 87\% and $70 \%$ of people were aware of this subject, respectively. The nature of the questions in the questionnaire may have contributed to the worse result observed in this study. A closed questions which could overestimate the participants' knowledge were used in foreign studies, while in the current study an open questions were used. Also in Kung and Lee (7) studies only $23.2 \%$ of Chinese women aged $>50$ years living in Hong Kong mentioned the sun as a source of vitamin D. The percentage of this answer increased to $52.6 \%$ when the question with the proposed answers was used (7) .

Only $58 \%$ of the study group (175 people) knew about the richest exogenous source of vitamin D, which are fish, but only 10 people precisely indicated oily sea fish. Other valuable dietary product sources were mentioned with much less frequency, milk and milk products had the greatest number of indications, which was also observed in similar studies from central Poland (8) and Ireland (9). Dairy products are the basic source of calcium in the diet, but it contains trace amounts of vitamin D (for cow's milk: 0.4-1.2 $\mathrm{IU} / 100 \mathrm{ml})$. In Poland, it is only obligatory to fortify fat spreads and baby formula with vitamin D (10), so in order to meet the daily requirement of 800 IU (20 $\mu \mathrm{g}$ ) one would have to drink over 80 liters of milk a day. In this study, the least knowledge of the dietary sources of vitamin D the youngest respondents. Products with a high content of cholecalciferol (fish, chicken eggs) was indicated the rarest and milk and dairy products most often. A similar trend was observed by Deschasaux et al. (6) in a cross-sectional study from 2016, on a representative group of nearly 60,000 inhabitants of France, where the frequency of indicating oily sea fish and cod-liver oil increased with age. In the groups $<35$ years, $35-55$ years old and $>55$ years old it was respectively: for fish $52 \%$, $59.4 \%$ and $69.5 \%$, and for cod-liver oil $41.7 \%, 51.6 \%$ and $66.2 \%$. The youngest group, on the other hand, more often indicated dairy products fortified with vitamin D (in France, as well as in Poland, it is an optional fortification depended on a manufacturer). The authors suggested that the better knowledge presented in the oldest age group could have been influenced by the preventive administration of a codliver oil in schools in the 1960s and 70s (6).

Compared to solar radiation, dietary sources are a little contribution to the supply of vitamin
Głównym źródłem informacji na temat witaminy D były dla respondentów środki masowego przekazu: internet (55\%), telewizja (28,7\%) i prasa $(18,7 \%), 20,7 \%$ osób zostało poinformowanych przez członków rodziny lub znajomych, 14\% wskazało na edukację szkolną, a jedynie $9,7 \%$ osób uzyskało informację od lekarza lub innego personelu medycznego.

\section{DYSKUSJA}

Uzyskane w badanej próbie wyniki ujawniły poważny deficyt wiedzy dotyczącej źródeł witaminy D. O promieniowaniu słonecznym, głównym źródle witaminy D dla organizmu człowieka, wiedziało zaledwie $59 \%$ respondentów. W podobnych badaniach przeprowadzonych w Wielkiej Brytanii (5) oraz Francji (6) wiedzę na ten temat posiadało odpowiednio: $87 \%$ i $70 \%$ osób. Na wyraźnie gorszy wynik obserwowany w niniejszym badaniu mógł wpłynąć typ pytań zawartych w kwestionariuszu. W pracach zagranicznych zastosowano pytania zamknięte, co mogło przeszacować wiedzę uczestników, podczas gdy w obecnym badaniu posłużono się pytaniem otwartym. Również w pracy Kung i Lee (7) jedynie 23,2\% chińskich kobiet, w wieku $>50$ lat zamieszkujących Hongkong, wymieniło słońce jako źródło witaminy D. Odsetek wskazań tej odpowiedzi zwiększył się do 52,6\%, gdy zastosowano pytanie z proponowanymi odpowiedziami (7).

O najbogatszym źródle egzogennym witaminy $\mathrm{D}$, jakim są ryby, wiedziało jedynie 58\% ankietowanych $(n=175)$, jednak tylko 10 osób precyzyjnie podało tłuste ryby morskie. Podczas gdy inne wartościowe źródła dietetyczne wymieniane były z dużo mniejszą częstością, największą liczbę wskazań miało mleko i przetwory mleczne, co zaobserwowano również w podobnych badaniach z centralnej Polski (8) i Irlandii (9). Nabiał jest podstawowym źródłem wapnia w diecie, jednak zawiera jedynie śladowe ilości witaminy D (dla mleka krowiego: 0,4-1,2 IU/100ml). W Polsce jego obligatoryjna fortyfikacja witaminą $\mathrm{D}$ dotyczy tylko tłuszczów do smarowania pieczywa oraz mleka modyfikowanego dla niemowląt (10), aby więc zaspokoić dobowe zapotrzebowanie rzędu $800 \mathrm{IU}(20 \mu \mathrm{g})$ należałoby wypić ponad 80 litrów mleka dziennie. W niniejszym badaniu najmniejszą wiedzę na temat źródeł pokarmowych witaminy D posiadała grupa najmłodszych respondentów: najrzadziej podawali produkty z dużą zawartością cholekalcyferolu (ryby, jaja kurze) a najczęściej mleko i produkty mleczne. Podobny trend zaobserwował Deschasaux i wsp. (6) w badaniu przekrojowym z 2016 roku, na reprezentatywnej grupie blisko 60 tysięcy mieszkańców Francji, gdzie częstość wskazywania tłustych ryb morskich oraz tranu rosła wraz $\mathrm{z}$ wiekiem. W grupach $<35$ lat, 35-55 lat $\mathrm{i}>55$ lat było to odpowiednio: dla ryb $52 \%, 59,4 \%$ i $69,5 \%$ oraz dla tranu $41,7 \%$, 
D. However, knowledge about them, including appropriate products in the daily diet, can reduce the existing hypovitaminosis, especially when for various reasons, sun exposure is limited. In this study, the respondents' knowledge of the dietary sources of vitamin D turned out to be insufficient. Additionally, only $37 \%$ of people were aware that even a well-balanced diet is not able to provide the daily requirement for this vitamin. In comparison, in the study performed by O'Connor et al. (5) in 2018, as many as $68 \%$ of people were aware of this fact. In this study, people from the oldest age group had the best knowledge about the nutritional sources of vitamin $\mathrm{D}$, but most people from this group had a misconception that it is possible to meet the daily requirement for vitamin $\mathrm{D}$ with a balanced diet.

$78 \%$ of the study group were aware of the calcemic effect of vitamin D, while the pleiotropic effects were known by a smaller part of the group. In 2018 Zadka et al. (8) also used open questions in their study, the calcemic effect of vitamin D was indicated by $66 \%$ of a school child's parents. Pleiotropic effects were mentioned with a similar frequency as in this manuscript. For example, 19\% of people were aware of the strengthening immunity, a positive effect on the nervous and cardiovascular systems was mentioned by $8 \%$ and $3 \%$ of the group, respectively, and only $2 \%$ of the respondents were aware of the anti-cancer effect (8). After using closed questions in the present study, regarding the health consequences of vitamin D deficiency, the assessment of knowledge increased significantly (e.g. the influence on the immune system in the open question was provided by $24 \%$ of the group, while in the closed question, immune disorders were indicated by $50 \%$ of the respondents). The frequency of indicating particular disease was comparable to the results of Deschasaux et al. (6), where closed questions were also used.

In the present study women had a better knowledge of the sources, functions and health consequences of vitamin D deficiency, similar as in other reports (5$6,11-13)$. This may be due to the fact that women, as a group at higher risk of osteoporosis, were more interested in topics related to nutrition and health.

According to the recommendation of the National Institute of Public Health - National Institute of Hygiene in Poland, exposure of at least $18 \%$ of the body surface to solar radiation, without any sunscreen, for 15 to 20 minutes between 10am$3 \mathrm{pm}$ is safe and sufficient to achieve optimal serum 25(OH)D level (1). The lack of knowledge about the minimum time of sun exposure sufficient for vitamin D synthesis, observed in this study, was associated with the risk of adverse health consequences of excessive sun exposure (burns, photo-damage, e.g.
51,6\% i 66,2\%. Grupa najmłodsza częściej natomiast wskazywała na fortyfikowane witaminą D produkty mleczne (we Francji tak jak i w Polsce jest to fortyfikacja dobrowolna stosowana przez producenta). Autorzy sugerują, że na lepszą wiedzę osób z najstarszej grupy wiekowej mogło wpłynąć profilaktyczne podawanie tranu w szkołach w latach 60. i 70. XX wieku (6).

Źródła dietetyczne, w porównaniu do promieniowania słonecznego, w niewielkim stopniu przyczyniają się do zaopatrzenia organizmu $\mathrm{w}$ witaminę D. Jednakże wiedza na ich temat, poprzez włączenie odpowiednich produktów do dziennego jadłospisu, może przyczynić się do zmniejszenia istniejącej hipowitaminozy, zwłaszcza kiedy z różnych względów ograniczona jest ekspozycja na słońce. W niniejszym badaniu wiedza respondentów na temat źródeł pokarmowych witaminy D okazała się niesatysfakcjonująca. Dodatkowo jedynie $37 \%$ osób było świadomych, że nawet dobrze zbilansowana dieta nie jest w stanie zapewnić dobowego zapotrzebowania na tę witaminę. Dla porównania, w badaniu O’Connor i wsp. (5) z 2018 roku, świadomość tego faktu posiadało aż $68 \%$ osób. W niniejszym badaniu osoby z najstarszej grupy wiekowej posiadały najlepszą wiedzę odnośnie źródeł pokarmowych witaminy $\mathrm{D}$, jednakże najwięcej osób $\mathrm{z}$ tej grupy miało błędne przekonanie o możliwości zaspokojenia dziennego zapotrzebowania na tę witaminę zbilansowaną dietą.

$78 \%$ respondentów wiedziało o kalcemicznym działaniu witaminy D, natomiast funkcje plejotropowe były znane przez mniejszą część grupy. W badaniu Zadka i wsp. (8) z 2018 roku, w którym również zastosowano pytania otwarte, przeprowadzonym wśród rodziców dzieci szkolnych, na funkcję kalcemiczną witaminy D wskazało 66\% osób. Działania plejotropowe wymieniane były z podobną jak w obecnej pracy częstością. Przykładowo, o wzmacnianiu odporności wiedziało 19\% osób, pozytywny wpływ na układ nerwowy i sercowo -naczyniowy wymieniło odpowiednio 8\% i 3\% grupy, a o działaniu przeciwnowotworowym było świadomych tylko $2 \%$ ankietowanych (8). Po zastosowaniu w obecnym badaniu pytań zamkniętych, dotyczących konsekwencji zdrowotnych niedoboru witaminy D, ocena wiedzy ankietowanych znacząco wzrosła (np. wpływ na układ immunologiczny przy pytaniu otwartym podało 24\% grupy, natomiast zaburzenia odporności przy pytaniu zamkniętym wskazało $50 \%$ ankietowanych). Częstość wskazywania danych jednostek chorobowych była porównywalna do wyników pracy Deschasaux i wsp. (6), gdzie również zastosowano pytania zamknięte.

W obecnym badaniu, podobnie jak w innych doniesieniach $(5-6,11-13)$, kobiety posiadały lepszą wiedzę na temat źródeł, funkcji i następstw zdrowotnych niedoboru witaminy D. Może być to spowodowane większym zainteresowaniem kobiet, jako grupy bardziej 
cancer). The similar results were presented by Smuda et al. (13) in 2018 , only $12.3 \%$ of the respondents indicated the correct answer, nearly half declared lack of knowledge, and the rest marked longer solar exposure periods of time. In the study by Bonevski et al. (12), conducted in 2012 in Australia, among general practitioners, only $7 \%$ of physicians knew the recommendations regarding safe sun exposure, the rest chose periods of time longer than recommended (12). In Australia, due to the high UV index, the safe sun exposure time is 2 to 6 minutes in summer and 4-17 minutes in the winter months.

The effectiveness of cutaneous calciferol synthesis depends on a number of factors. At Poland latitude $\left(49^{\circ} \mathrm{N}-54^{\circ} 50^{\prime} \mathrm{N}\right)$, the angle of sunlight is insufficient for the synthesis of vitamin $\mathrm{D}$ in the months from October to March and in hours other than around noon. Most of the respondents correctly indicated the time of year and time of day, while nearly half of the group, mainly women, weren't aware of the influence of latitude. Other factors limiting the skin synthesis of vitamin D were provided with less frequency, as in the study of O'Connor et al. (5). In this study, men and better educated respondents were more aware of the limiting effects of cloud cover, air pollution, the use of sunscreens and skin pigment content on endogenous vitamin D synthesis. Most of the group knew that the elderly were at higher risk of vitamin D deficiency, on the other hand, obesity as a risk factor was indicated only by $30 \%$ of people, mainly men.

The low consumption of foods rich in vitamin $\mathrm{D}$ shown in this study, may be explained by insufficient knowledge about its dietary sources. Both the worst knowledge about exogenous sources and the lowest consumption of fish, red meat, eggs and butter, especially in the youngest age group confirmed it. On the other hand, in the group of women, greater knowledge of vitamin D sources did not have a positive effect on nutritional behaviour, despite better knowledge in this area compared to men, no increased intake of vitamin $\mathrm{D}$ in the diet was observed.

Due to the Poland latitude and the modern lifestyle when people stays indoors for most of the day, the Polish Team of Experts in cooperation with the European Vitamin D Association - EVIDAS recommends vitamin D supplementation (3). Despite the current recommendations, only $45 \%$ of the surveyed group declared using supplements of this vitamin. It should also be mentioned, that only less than half of the group declared to be regular in supplementation. Similar results were obtained by O'Connor et al. (5), where from $43.5 \%$ of people using supplements, $77 \%$ do it every day. In other reports, the percentages of people taking vitamin D supplements narażonej na osteoporozę, tematyką związaną z żywieniem i zdrowiem.

W warunkach polskich zgodnie z rekomendacją Narodowego Instytutu Zdrowia Publicznego - Państwowego Zakładu Higieny, ekspozycja co najmniej 18\% powierzchni ciała na promieniowanie słoneczne bez stosowania preparatów promieniochronnych, wynosząca od 15 do 20 minut w godzinach $10-15$, jest bezpieczna i wystarczająca do osiągnięcia optymalnego stężenia 25(OH)D w surowicy (1). Obserwowany w niniejszym badaniu, u większości osób, brak wiedzy na temat minimalnego czasu wystarczającego do syntezy witaminy $\mathrm{D}$, wiąże się z ryzykiem wystąpienia niekorzystnych następstw zdrowotnych nadmiernej ekspozycji słonecznej (oparzenia, fotouszkodzenia np. nowotwory). Podobnie wyniki przedstawiono w badaniu Smudy i wsp. (13) z 2018 roku, gdzie zaledwie 12,3\% respondentów zaznaczyło poprawną odpowiedź, blisko połowa zadeklarowała brak wiedzy, a pozostałe osoby wskazały dłuższe czasy ekspozycji słonecznej. W badaniu Bonevski i wsp. (12), przeprowadzonym w 2012 roku w Australii, wśród lekarzy ogólnych, jedynie 7\% medyków znało rekomendacje dotyczące bezpiecznego czasu przebywania na słońcu, pozostali wybierali czas dłuższy od zalecanego (12). W Australii, ze względu na wysoki indeks UV, długość bezpiecznej ekspozycji wynosi od 2 do 6 min latem i 4-17 min w miesiącach zimowych.

Efektywność skórnej syntezy kalcyferolu zależna jest od szeregu czynników. W szerokości geograficznej, w której położona jest Polska $\left(49^{\circ} \mathrm{N}-54^{\circ} 50^{\prime} \mathrm{N}\right)$, kąt padania promieni słonecznych jest niewystarczający do syntezy witaminy D w miesiącach od października do marca, oraz w godzinach innych niż okołopołudniowe. Większość ankietowanych poprawnie wskazało na porę roku oraz porę dnia, natomiast o wpływie szerokości geograficznej nie wiedziała blisko połowa grupy, głównie kobiety. Pozostałe czynniki ograniczające skórną syntezę witaminy D wskazywane były z mniejszą częstością, podobnie jak w pracy O’Connor i wsp. (5). W niniejszym badaniu, mężczyźni oraz respondenci lepiej wykształceni mieli większą świadomość ograniczającego wpływu zachmurzenia, zanieczyszczenia powietrza, stosowania preparatów promieniochronnych oraz zawartości pigmentu w skórze na endogenną produkcję witaminy D. Większość grupy wiedziała, że osoby starsze są bardziej narażone na ryzyko wystąpienia niedoboru witaminy $\mathrm{D}$, natomiast na otyłość, jako czynnik ryzyka, wskazało zaledwie $30 \%$ osób, głównie byli to mężczyźni.

Wykazane w obecnym badaniu niskie spożycie produktów bogatych w witaminę D można thumaczyć niedostateczną wiedzą na temat jej źródeł dietetycznych. Znajduje to potwierdzenie zwłaszcza u osób z najmłodszej grupy wiekowej, które wykazały się zarówno naj- 
were much lower: in two studies conducted in Poland in 2018 , it was $22.4 \%$ (13) and $26.2 \%$ (8), and in the study by Deschasaux et al. (6) only $12.9 \%$.

The supplementation dose should be adjusted based on the total $25(\mathrm{OH}) \mathrm{D}$ level in blood. In the study, this preventive action was taken by less than $7 \%$ of respondents, which was a symptom of low social awareness of the necessity to monitor blood levels of vitamin D. For comparison, in the O'Connor et al. (5) study it was $13 \%$ and in the study performed by Smuda et al. (13) in the same year it was $14.7 \%$, from which only $5.1 \%$ performed the survey in the last six months. However, in a study conducted by Salmanpour et al. (11) in 2016, only 3\% of the inhabitants of the Arabian Peninsula measured a 25(OH)D level.

Despite the fact that nearly $70 \%$ of the respondents expressed their concern about skin cancer, threequarters of the respondents presented a positive attitude to direct sunlight. For comparison, in the study performed by O'Connor et al. (5), $56 \%$ of the respondents had a positive attitude. Despite the knowledge of the benefits of sun exposure, $62.3 \%$ of Chinese women did not spend time in the sun, probably for cosmetic reasons to maintain a light skin tone (7). In subtropical zone countries where vitamin D deficiencies are common, despite high sun exposure, a negative attitude was observed: $53.5 \%$ of women from Saudi Arabia declared no sun exposure (14), and among the inhabitants of the United Arab Emirates, over three-quarters avoided the sun (11). In Arab countries, cultural and religious reasons (covering the body with clothes) are mainly responsible for the formation of vitamin D deficiency, while in Poland the main contributing factor is climatic conditions.

Professional sources of knowledge, such as healthcare professionals or school education, were the least popular. For comparison, in the work of Deschasaux et al. (6) $41 \%$ of respondents mentioned medical personnel and $18 \%$ mentioned school. Similarly to the works of O'Connor et al. (5) and Kotta et al. (15), the media were mentioned most often in this study, which may explain the insufficient level of knowledge.

\section{CONCLUSIONS}

Insufficient knowledge about the vitamin D sources, misconceptions about the possibility to reach adequate blood levels through the diet, and at the same time low consumption of products rich in vitamin D and its supplements, observed in this study, increase the risk of developing hypovitaminosis among the inhabitants of the GZM Metropolis. Women had a better knowledge of the sources of gorszą wiedzą na temat źródeł egzogennych, jak również najniższym spożyciem ryb, czerwonego mięsa, jaj oraz masła. Z kolei w grupie kobiet większa znajomość źródeł pokarmowych witaminy D nie wpłynęła korzystnie na zachowania żywieniowe, gdyż pomimo lepszej, w porównaniu do mężczyzn, wiedzy w tym zakresie nie zaobserwowano zwiększonego spożycia witaminy $\mathrm{D}$ wraz z dietą.

Ze względu na szerokość geograficzną Polski oraz obecny styl życia, polegający na przebywaniu w pomieszczeniach zamkniętych przez większą część dnia, polski Zespół Ekspertów we współpracy z Europejskim Towarzystwem Witaminy D - EVIDAS zaleca suplementację witaminy D (3). Pomimo aktualnych rekomendacji, zaledwie $45 \%$ ankietowanych deklarowało przyjmowanie suplementów tej witaminy. Należy również wziąć pod uwagę, że mniej niż połowa grupy suplementującej wykazała się systematycznością. Podobne wyniki uzyskał O'Connor i wsp. (5), gdzie osoby przyjmujące suplementy stanowiły $43,5 \%$, w tym $77 \%$ przyjmowało preparat codziennie. W pozostałych doniesieniach odsetek osób zażywających suplementy witaminy D był znacznie niższy: w dwóch badaniach przeprowadzonych w Polsce w 2018 roku wynosił $22,4 \%$ (13) i 26,2\% (8), a w badaniu Deschasaux i wsp. (6) zaledwie $12,9 \%$.

Dawka stosowanego suplementu powinna być ustalana w oparciu o pomiar stężenia $25(\mathrm{OH}) \mathrm{D}$ w surowicy. $\mathrm{W}$ niniejszej pracy to prewencyjne działanie podjęło mniej niż 7\% ankietowanych, co jest przejawem niskiej świadomości społecznej dotyczącej konieczności monitorowania stanu zaopatrzenia organizmu w witaminę D. Dla porównania, w pracy O'Connor i wsp. (5) badanie to przeprowadziło 13\% ankietowanych, w badaniu Smudy i wsp. (13), przeprowadzonym w tym samym czasie w Polsce, było to $14,7 \%$ osób, z czego zaledwie 5,1\% wykonało badanie w ciągu ostatniego półrocza, natomiast w badaniu przeprowadzonym przez Salmanpour i wsp. (11) w 2016 roku zaledwie 3\% mieszkańców Półwyspu Arabskiego oznaczyło stężenie 25(OH)D.

Pomimo tego, że blisko $70 \%$ osób ankietowanych wyraziło obawę przed nowotworami skóry, $3 / 4$ respondentów prezentowało pozytywne nastawienie do bezpośredniej ekspozycji słonecznej. Dla porównania, w badaniu O'Connor i wsp. (5) taką pozytywną postawę miało $56 \%$ ankietowanych. Pomimo wiedzy o korzyściach wynikających z nasłonecznienia, $62,3 \%$ Chinek nie spędzało czasu na słońcu, prawdopodobnie ze względów kosmetycznych dla zachowania jasnego odcienia skóry (7). W badaniach prowadzonych w państwach strefy zwrotnikowej, w których pomimo dużego nasłonecznienia niedobory witaminy D są powszechne, obserwowane było nastawienie negatywne: $53,5 \%$ kobiet z Arabii Saudyjskiej deklarowało brak ekspozycji słonecznej (14), a wśród mieszkańców Zjednoczonych 
vitamin $\mathrm{D}$, but it did not affect their attitude to sun exposure or increased consumption of products rich in this vitamin, but they took supplements more often. People in the youngest age group had the worst knowledge about dietary sources of cholecalciferol and consumed the least foods rich in this vitamin.

Most of the study group had a positive attitude to spend time in the sun, but did not know the safe time of daily sun exposure, the knowledge about the factors limiting dermal synthesis was also insufficient. Prevention of vitamin D deficiency should become a priority of health policy and health care in the GZM Metropolis. Easy-to-read social messages containing apart from the time of day and year, other factors influencing the skin synthesis of vitamin $\mathrm{D}$, supported by current knowledge, should be considered. These recommendations should balance the prevention of vitamin $\mathrm{D}$ deficiency with protection against the adverse effects of UV radiation.

\section{REFERENCES}

1. Jarosz M [red.]: Normy żywienia dla populacji Polski. Warszawa: Narodowy Instytut Zdrowia Publicznego - Państwowy Zakład Higieny (NIZPPZH), 2020: 177-180.

2. Holick MF. The vitamin D deficiency pandemic: Approaches for diagnosis, treatment and prevention. Rev Endocr Metab Disord 2017; 18: 153-165.

3. Rusińska A, Płudowski P, Walczak M i wsp. Zasady suplementacji i leczenia witaminą D - nowelizacja 2018 r. Postępy Neonatologii 2018; 24: 1-24.

4. Płudowski P, Ducki C, Konstantynowicz J et al. Vitamin D status in Poland. Pol Arch Med Wewn 2016; 126: 530-539.

5. O'Connor C, Glatt D, White L et al. Knowledge, attitudes and perceptions towards vitamin $\mathrm{D}$ in UK adult population: a cross-sectional study. Int J Environ Res Public Health 2018; 15: 2387. doi: 10.3390/ijerph15112387.

6. Deschasaux M, Souberbielle JC, Partula V et al. What do people know and believe about vitamin D? Nutrients 2016; 8: 718. doi.org/10.3390/nu8110718

7. Kung A, Lee K. Knowledge of vitamin D and perceptions and attitudes toward sunlight among Chinese middle-aged and elderly women: a population survey in Hong Kong. BMC Public Health 2006; 6: 226. doi.org/10.1186/1471-2458-6226

8. Zadka K, Pałkowska-Goździk E, RosołowskaHuszcz D. The state of knowledge about nutrition sources of vitamin D, its role in the human body, and necessity of supplementation among parents in central Poland. Int J Environ Res Public Health 2018; 15: 1489. doi:10.3390/ijerph15071489
Emiratów Arabskich ponad 3/4 unikało słońca (11). W państwach arabskich za powstawanie niedoborów witaminy D odpowiedzialne są głównie względy kulturowe i religijne (zakrywanie ciała ubiorem), podczas gdy w Polsce głównym czynnikiem sprawczym są warunki klimatyczne.

Profesjonalne źródła wiedzy, takie jak pracownicy ochrony zdrowia czy edukacja szkolna, były najmniej popularne wśród respondentów. Dla porównania w pracy Deschasaux i wsp. (6) aż $41 \%$ ankietowanych podało personel medyczny, a $18 \%$ szkołę. Media, podobnie jak w pracach O'Connor i wsp. (5) i Kotta i wsp. (15), wymieniane były w niniejszym badaniu najczęściej, co może stanowić wyjaśnienie niezadawalającego poziomu wiedzy jego uczestników.

\section{WNIOSKI}

Niedostateczna wiedza o źródłach witaminy D, błędne przekonanie o możliwości zapewnienia odpowiedniego zapotrzebowania poprzez dietę, jak również niskie spożycie produktów bogatych w witaminę D i jej suplementów, zaobserwowane w niniejszym badaniu, zwiększają ryzyko rozwoju hipowitaminozy wśród mieszkańców Górnośląsko-Zagłębiowskiej Metropolii. Kobiety posiadały lepszą wiedzę o źródłach witaminy $\mathrm{D}$, jednak nie wpłynęła ona na ich nastawienie do ekspozycji słonecznej ani na większe spożycie produktów bogatych w tę witaminę, częściej natomiast zażywały jej suplementy. Osoby z najmłodszej grupy wiekowej posiadały najgorszą wiedzę na temat źródeł dietetycznych cholekalcyferolu i spożywały najmniej produktów bogatych w tę witaminę.

Większość badanej grupy miała pozytywne nastawienie do przebywania na słońcu, nie znała jednak bezpiecznego czasu dziennej ekspozycji słonecznej, a wiedza na temat czynników ograniczających skórną syntezę była niewystarczająca. Profilaktyka niedoboru witaminy D powinna stać się priorytetem polityki zdrowotnej i służby zdrowia na obszarze GZM. Należy rozważyć proste w odbiorze komunikaty społeczne, poparte aktualną wiedzą, uwzględniające oprócz pory dnia i roku, pozostałe czynniki wpływające na skórną syntezę witaminy D. Rekomendacje te powinny równoważyć przeciwdziałanie niedoborom witaminy $\mathrm{D}$ z ochroną przeciwko niekorzystnym skutkom promieniowania UV.

9. Toher $\mathrm{C}$, Lindsay $\mathrm{K}$, McKenna $\mathrm{M}$ et al. Relationship between vitamin D knowledge and 25-hydroxyvitamin D levels amongst pregnant women. J Hum Nutr Diet 2014; 27: 261-269.

10. Rozporządzenie Ministra Zdrowia $\mathrm{z}$ dnia 16 września $2010 \quad$ r. $\quad w$ sprawie substancji 
wzbogacających dodawanych do żywności, Dz. U. $2010 \mathrm{nr}$ 174, poz. 1184.

11. Salmanpour VA, Ibrahim HS, Salameh AG et al. Vitamin D deficiency: knowledge and practices among the adult population in Sharjah, United Arab Emirates. Arch Osteoporos 2016; 11: 15. doi. org/10.1007/s11657-016-0269-0

12. Bonevski B, Girgis A, Magin, $P$ et al. Prescribing sunshine: a cross-sectional survey of 500 Australian general practitioners' practices and attitudes about vitamin D. Int J Cancer 2012; 130: 2138-2145.

13. Smuda A, Baran A, Brzozowska A i in. Wiedza społeczeństwa na temat roli witaminy D3 oraz konieczności monitorowania stężenia jej metabolitu we krwi. Kosmetologia Estetyczna 2018; 7: 19-25.

14. Habib FM, Al-Motairi WA, Al-Mutairi WM. Vitamin D deficiency: knowledge and practice among adult Saudi females. Glo Adv Res J Med Med Sci 2014; 3: 95-101.
15. Kotta S, Gadhvi D, Jakeways N et al. "Test me and treat me"-attitudes to vitamin D deficiency and supplementation: a qualitative study. BMJ Open 2015; 5: e007401. doi:10.1136/ bmjopen-2014-007401

Received: 14.07.2021

Accepted for publication: 01.09.2021

Otrzymano: 14.07.2021 r.

Zaakceptowano do publikacji: 01.09.2021 r.

\section{Address for correspondence:}

Adres do korespondencji:

dr n. med. Magdalena Kamińska

Katedra Podstawowych Nauk Biomedycznych

Śląski Uniwersytet Medyczny w Katowicach

Wydział Nauk Farmaceutycznych

e-mail: mkaminska@sum.edu.pl

tel. 322699830 